\title{
10 Turkey: Between East and West
}

METIN HEPER

I spent the 1986-7 academic year at the University of Manchester, in the United Kingdom, as a research fellow. On one occasion I asked a faculty member there who taught Middle Eastern politics what kind of material on Turkey he used in his course. The response I received was 'Well, in my course we don't cover Turkey. After all, Turkey is not really a Middle Eastern country.' A few days later I directed the same question to another colleague, who offered a course on European politics. I again received a 'not really' answer.

The fact that Turkey is construed to be neither completely European nor Middle Eastern makes it an interesting case study for the purpose of the present volume, the editors of which plausibly argue that the security community they would like to see develop around the Mediterranean should be a pluralistic one, and thus should rest on the sharing of identities and not on a shared identity. That Turkey is the only Muslim country with a fairly well consolidated democracy is an additional reason to focus on the experience of that country because, as the editors again sensibly argue, pluralistic security communities can flourish only in those regions that are socially constructed in such a manner that they transcend cultural and civilizational borders.

The editors of the present volume also do not neglect to point out that cross-cultural and, even more importantly, cross-civilizational projects have become all the more important in the post- $9 / 11$ period, when the (earlier) idea of a 'clash of civilizations' was revived. After 9/11, Turkey took its position on the side of the United States in the latter's war on terror, to the extent to which its democratic institutions, including its Parliament, allowed. ${ }^{1}$ Since November 2002 the country has been ruled by the Justice and Development Party (Adalet ve Kalkınma Partisi, or 
AKP) government; although it is often referred to as a religiously oriented party, the leaders of the AKP, though pious themselves, define the government they have formed as a 'conservative-democratic' one. They argue that although they themselves are pious Muslims, their government is a secular one. As such, the Turkish experience refutes the 'clash of civilizations' argument (Heper, forthcoming).

It should also be noted here that Turkey became an associate member of what is today the European Union (EU) in 1963, and - particularly during recent years, in its quest to become a full member of the EU - it has not rejected the 'normative power' of that union and has taken important steps to align its political and economic system to the norms drawn up at Maastricht and Copenhagen.

The last but not least reason why one should include Turkey in the present study is based on the assumption that a long-lasting peace and harmony in the region would develop only if the individual countries went through a process of learning themselves, and thus the adaptation of the individual countries to this new world would primarily be the upshot of an endogenous, rather than an exogenous, change. Turkey has been one of those exceptional countries that started to transform its identity from an Eastern to a Western one, from the end of the eighteenth century onward, of its own volition.

In what follows, first, the Ottoman and Turkish attitudes and values that came to have a close semblance to those of the Europeans and the causes behind that particular development are discussed. Second, the issue of if and to what extent the seemingly problematic questions of Islam in politics, nationalism, and the role of the military in politics in Turkey interfered with the growing similarities between European and Ottoman-Turkish attitudes and values is addressed. Finally, given the lessons one may derive from the Ottoman-Turkish experience, some suggestions are offered on how one should proceed in starting to build a pluralistic, loosely coupled security environment around the Mediterranean.

\section{Turkey and the West}

Starting in the last decades of the eighteenth century, the Turks gradually came to have a European vocation, which was facilitated by their close contact with the West. Following the foundation of the Ottoman state about 1299, a great deal of mutual acculturation had taken place between the Byzantines and the Turks. During the later centuries, 
Christians, Jews, and Muslims similarly influenced one another in the empire that the Turks built. The Turks either fought their European adversaries or had trade relations with them. Many European merchants, scholars, among others, travelled in the Ottoman lands; quite a few came to stay. Some converted to Islam. The latter played an important role in establishing communications and maintaining links between the Turks and Europeans (Lewis 1961).

From the early fifteenth century to the second half of the sixteenth century, as their empire expanded on three continents - Africa, Asia, and Europe - the Turks found themselves in the midst of European politics. For example, on different occasions, Francis I, the king of France and a candidate for the Hungarian throne, requested the help of Ottoman sultan Suleiman the Magnificient (who reigned 1520-66) against the Hapsburgs. Although from the seventeenth to the eighteenth century the Ottoman Empire experienced a virtually constant decline, it never became a colony. Consequently, the Turks never harboured any deep resentment towards the Europeans. Thus, when they started to lose continuously against them in the battlefield, they did not hesitate to 'borrow the infidel's ways in order to overcome them.' For instance, as early as 1719 , they sent an ambassador to Paris in order to determine which aspects of European civilization that they could usefully adopt (ibid.).

The fact that, as compared to other Islamic states, the Ottoman Empire was the least Islamic (İnalcık 1968-70) was also a contributing factor to the ease with which the Turks turned their face to the West. Islam played a relatively less significant role in Ottoman statecraft because it was recognized that Islam basically regulated the personal life and interpersonal relations of Muslims, but that it had little to contribute to public affairs. More significantly, having developed into an empire that comprised several religions, sects, and/or ethnic groups, the Ottoman state could ill afford to impose an orthodox version of Islam upon its mosaic. Greek Orthodox, Gregorian Armenians, and Jews constituted separate religious communities. For the most part, their clergy and lay heads, who had authority concerning religious administration, worship, education, and charity as well as the supervision of the civil status of their co-religionists, governed these communities (Braude and Lewis 1982).

From about the sixteenth century onward, a secular state philosophy based on the notions of 'necessity' and 'reason' competed with Islamic prescriptions. During the nineteenth century, when in other Muslim 
countries efforts were made to reconcile Islam with modernization, the Turks subscribed to the so-called cast-iron theory of Islam, the idea that Islam had remained far behind the contemporary developments and could not be adapted to them (Yalman 1969, 41-2). Consequently, the founders of the Republic (established in 1923) could adopt the following dictum of a late Ottoman intellectual, Abdullah Cevdet: 'There is no second civilization. Civilization means European civilization. It must be imported with both its roses and thorns' (Rustow 1987, 14). They thus started a program of radical social and cognitive change, which has been referred to as a 'cultural revolution' (Mardin 1971). The major goal was the secularization of polity and society. Having arrived at the conclusion that the Islamic institution alone was to be blamed for the demise of the Ottoman Empire ('because it stood in the way of more comprehensive reforms to save the Empire'), the founders aimed at creating a new Turk who would not take his/her cues from Islam but would draw upon his/her own reasoning faculties (Karpat 1959). Among other things, they abolished the Caliphate, the symbolic head of all Muslims in the world; replaced the religious courts with secular counterparts; introduced a Western educational system from grade school to university; substituted the Latin alphabet, the common origin of European culture, for traditional Arabic-Islamic script; embraced European theatre and music; and adopted law codes from different European countries. The new Civil Code of 1926, taken intact from Switzerland, aimed at emancipating people from Islam in their social and economic life. The ultimate goal pursued by the founders was the reformation, rather than the renaissance, of Islam. The school textbooks of the 1920s contained such prescriptions as 'A Muslim truly worthy of that name has to love his country, respect the laws of the Republic, submit to the progressive guidance of the state officials, apply scrupulously the principles of good hygiene, consult a doctor in the case of an illness to avoid being the cause of an epidemic, and work energetically for the development of his country' (Dumont 1987, 6).

These and other reforms came to have a significant impact on the identity of the Turks and on their views about the role that Islam should play in their daily lives. Empirical data show that, increasingly, being a Muslim was no longer an essential dimension of the identity of the people. In the late 1960s, when asked, 'How do you see yourselves?' 50.3 per cent of workers in a textile factory in the city of Izmir (Smyrna) on Turkey's Aegean coast considered themselves Turks and 37.5 per cent Muslims. In a 1994 nationwide survey, 69 per cent identi- 
fied themselves as Turks, 21 per cent as Muslim Turks, and only 4 per cent as Muslims. (Another 4 per cent said they were Kurds, and the remaining 2 per cent mentioned other ethnic identities.) Only a century ago people in the same country had identified themselves as either Muslim or non-Muslim.

On the issue of the role that religion should play in the daily life in Turkey, in a 1986 survey, only 7 per cent of a national sample thought that the country should be ruled in accordance with sharia (Islamic) law (Heper 1997). Later research (1999) has shown that only 1 per cent of the respondents understood sharia in its true sense: as including, for example, stoning to death an adulteress or cutting off the hand of a thief. The rest viewed it as an ambiguous set of rules for leading a moral life. In 1996, in the city of Konya, one of the most religiously conservative cities in Turkey, people preferred English-language curriculum to intensive religious instruction in schools (Çarkoğlu and Toprak 1999; Çarkoğlu 2004).

In the republican period, Islam in Turkey evinced strong signs of the Durkheimian version of religiosity by providing basically a means for group solidarity. Many people resorted to religion when they sensed alienation. A 1971 study found that in the socio-economically least developed provinces in the country, attendance at Koran courses was the lowest, and in the most developed ones, attendance at those schools was the highest. According to another 1971 study, mosque going was highest among those recent urban migrants who were not economically successful and/or were devoid of traditional social support (Çarkoğlu and Toprak 1999). In Turkey, Islam was also perceived as a source of moral principles. As noted below, this was the original motive for establishing religiously oriented parties in the country.

At the turn of the twenty-first century, Turkey for the most part was made up of people who were cognitively Westernized. For instance, very few people voted for a party just because it was religiously oriented. On the other hand, for many people, Muslim and other communitarian values continued to be significant. Thus, as noted, present-day Turkey can be considered both an Eastern and a Western country. However, as also observed the traditional has not been an obstacle to the flourishing of the modern. Turkey continues to make progress in its economy and democracy. The country's recent efforts at becoming a full member of the EU have accelerated both these processes. In Turkey there is also a thriving private sector. The Turks have managed to substitute an export-oriented economy for an import-oriented one, thus 
resolving their chronic balance of payments problem. Not unlike several other countries, from time to time Turkey faced economic crises; however, it always managed to set its economy right in a relatively short period of time. As noted, at the turn of the twenty-first century, Turkey was the only Muslim country with a functioning democracy. Except for a handful of Islamic, leftist, and rightist radicals, democracy has long been 'the only game in town.' Last but not least, Turkey has developed extensive relations with countries both in the North and in the South (Öniş 1998; Togan and Balaubramanyam 1996; Özbudun 2000; Rubin and Heper 2002; Heper and Sayarı 2002; Müftüler-Baç 1997; Makofsky and Sayarı 2000).

Although Turkey has both an Eastern and a Western face, its Western credentials are more apparent. On the one hand, it is a member of the Organization of Islamic Countries. On the other, it belongs to the Council of Europe, the North Atlantic Treaty Organization (NATO), and the Organization for Economic Co-operation and Development (OECD). Turkey has also obtained a date from the EU for the start of accession negotiations. To many countries, it is a dependable ally with a relatively stable economy and a functioning democracy. These two characteristics go a long way to render Turkey politically stable and free from irredentist aspirations.

The Turks continue to modernize their country, sometimes despite the West. Turkey applied to the European Economic Community, the predecessor of the EU, as early as 1959; it was made an associate member in 1963. Ankara asked for full membership in 1987. However, Turkey was not given a date for accession negotiations until 2004. While some Islamists and some members of the secularly oriented intelligentsia with Third Worldist inclinations are against Turkey's developing closer relations with the EU countries, a great majority of the Turks continue to think that it should go on modernizing by drawing upon Western models. In 2004, 70 per cent of Turks were of the opinion that their country should join the EU as a full member.

\section{Islam in Politics}

The primary rationale behind the founding of the first openly religiously oriented party in the republican period, the National Order Party (Milli Nizam Partisi, or MNP), in 1970-1 was not that of promoting sharia rule in Turkey, but rather that of improving morality and virtue in that country. The idea for what might be considered an Islamic version of the Prot- 
estant ethic came from a certain Mehmet Zait Kotku, who was then sheikh of the Nakshibandi order. According to the MNP program, new generations of people in Turkey were to be patriotic, self-sacrificing, respectful of private property, and equipped with the latest expertise, so that Turkey would be the leading country in the scientific, technological, and civilizational race. The National Salvation Party (Milli Selamet Partisi, or MSP), the successor party to the MNP in the year 1973-80, further elaborated this view by arguing that the state was responsible for promoting moral development, which was perceived as a prerequisite for material development. The MNP-MSP project aimed at revitalizing some tenets of Islam presumed to lie dormant in the conscience of the people. As is patent, the programs of the two parties did not take Islam as an end in itself (a religious goal) but as a means for material development (a secular goal). In the same vein, the Welfare Party (Refah Partisi, or RP), the successor party to the MSP from 1983 to 1997, talked about 'Just Order' (Adil Düzen), referring to a social order that was both 'rational' and 'just.' The RP too had a secular mission - that of fulfilling the twin goals of political stability and economic development.

Despite the fact that all three political parties formally had platforms that did not aim at bringing back sharia rule, all of them were banned for having 'tinkered with the secular premises of the Republic,' the MNP and RP by the Constitutional Court and the MSP by the 1980-3 military interveners. The grounds on which they were banned included their attempts to turn a well-known former Byzantine church in Istanbul (Haghia Sofia) into a mosque, rendering Friday a weekend day, and objecting to the compulsory eight-year secular education, which was recommended by the National Security Council (Milli Güvenlik Kurulu, or MGK). Necmettin Erbakan, a professor of engineering who had obtained his PhD in Germany, led the MNP, MSP, and RP. He himself may not have been a subscriber to political Islam. However, the appeasement policy he pursued towards the radical members of the parties in question and of the media, as well as his own occasional provocative statements (probably made to the gallery), prepared the end of these political parties.

The last religiously oriented party, which was also banned by the Constitutional Court, was the Virtue Party (Fazilet Partisi, or FP), the successor party to the RP in 1997-2001. This party differed from the earlier religiously oriented parties in two important respects. First, its leader, Recai Kutan, was more moderate than Erbakan. Secondly, this party was split into two factions, one of them being a liberal faction that 
attempted to put an end to the party's too-close attachment to Islam. However, because the orthodox faction of the party had the upper hand (with some outside help from Erbakan), the FP too was closed by the Constitutional Court.

None of the four religiously oriented parties could survive in a political regime the Constitution of which forbade political parties based on Islam; in any case, from 1970 onwards these parties had consistently moved from the margins of the political spectrum to its centre. As compared to the MNP, the MSP tended to view the European Economic Community, the predecessor of the EU, in a more positive light. The party was for 'reform' only in some specific political institutions, and it acted more carefully about what to say, when, and where.

The RP in turn perceived secular and Islamic world views as compatible. The party defined secularism as the feedom to practise one's religion according to one's beliefs without harassment. The RP also for the first time began to criticize members of the secular parties not as 'false Muslims' but as 'incompetent politicians.' In its political discourse, it made references to 'pluralist society,' 'basic rights and liberties,' 'more democracy,' 'privatization,' 'decentralization,' and 'globalization.' It was also in the RP period that women began to attend party congresses, and men began to wear neckties.

In the following FP period, secularization was defined in a more liberal direction: now religion was not going to interfere in the affairs of the state, and the state should leave religion alone. The party members were to avoid delivering sermons to the people; instead, they were expected to contribute to public policy-making. Intra-party criticisms began to take place. At party congresses, members challenged chairpersons for the leadership position. Women attended the party congresses with their hair uncovered and took their places in the local governments controlled by the party and in Parliament. Some of these women even consumed alcohol openly.

Upon the closure of the FP, not one but two successor parties were established. They were the Felicity Party (Saadet Partisi, or SP) and the Justice and Development Party (Adalet ve Kalkınma Partisi, or AKP). The SP is led by Kutan. It contains within its ranks some members of the orthodox factions of the earlier religiously oriented parties. However, the party is more moderate than its predecessor. In any case, it keeps a relatively low profile. In the November 2002 national elections, in all probability because of its closeness to Erbakan, the party could not return any members to Parliament. 
The AKP, led by the charismatic Recep Tayyip Erdoğan, was founded by members belonging to the liberal faction of the $\mathrm{SP}^{3}$ It is true that Erdoğan takes Islam as his basic reference. However, he derives from Islam a set of moral principles only for personal and, to some extent, communal life. He once observed: 'My reference is Islam at a personal level. Politically speaking, my reference is the Constitution and democratic principles.' He wishes people to elevate themselves to a higher pedestal of virtue, not through the establishment of a state based on Islam, but through personal self-improvement. Erdoğan does not make a distinction between practising and non-practising Muslims. He reasons that they were all created by God, and therefore they are all equal. He is against discriminatory behaviour towards non-Muslims too. His municipality in Istanbul (1994-8) helped to renovate not only mosques but also churches and synogogues in that city. Following the truck bombing of two synogogues in Istanbul, Erdoğan now prime minister, visited the chief rabbi and conveyed to him his condolences. He was accompanied by a seventy-strong AKP delegation that included several ministers. This was the first time in Turkish political history that a prime minister had visited the chief rabbi. Erdoğan once said: 'I don't think a person who is a genuine believer would harm the community no matter what his religion is. In all believers one comes across tolerance, love, and an instinct for helping fellow human beings.' In the wake of the truck bombing of the two synagogues in Istanbul, he called on all citizens to pool their resources in the combat against terrorism, adding that no monotheistic religion would tolerate, let alone encourage, terrorism.

Erdoğan thinks that a religiously oriented party is not a communal entity, embracing only a given religous, ethnic, or similar group. As such, it should open its arms to everybody. As a political leader, he believes in consultation to the widest extent possible. Erdoğan is for intra-party democracy. In the past, his discourse was coloured by themes and concepts derived from Islam. Consequently, his detractors accused him of being a subscriber to Islamic fundamentalism. He was even given a prison sentence of ten months. But Erdoğan has now left behind his habit of using Islamic terminology. He currently thinks that one should no longer call a struggle a jihad (holy war) when one is not trying to spread Islam by force, and similarly, one should not say he or she is for sharia when one is not interested in desecularizing the constitutional and legal system of the country.

At the November 2002 national elections, while the orthodox SP was wiped out of Parliament, the moderate AKP garnered a plurality of 
votes and formed a majority government. Although the secularist camp in general and the secularist military in particular have not looked with sympathy at a government headed by the AKP 'because of their belief in democracy as an end rather than as a means,' they have given that government the benefit of the doubt. In turn, led by Erdoğan, it has not disappointed at least the moderate elements of the secularist camp. Erdoğan has depicted the new government as 'conservative democratic' rather than Islamic. Indeed, the AKP government has placed such delicate issues as the turban controversy - the ban on the wearing of a turban in 'public places,' that is, in universities, state offices, and Parliament - on the back burner. When there were objections by the secularist camp to even the wives of cabinet ministers attending official functions with their hair covered, ministers began going to such functions without their wives.

If we turn from what it has not done to some of the things it has, the AKP government has made strenous efforts to make Turkey a full member of the EU, which have included Prime Minister Erdoğan's official visits to several EU countries, adoption of most of the measures the EU has posited as prerequisites for accession, maintaining close relations with the United States and Israel, and even lectures in other Muslim countries in the Middle East about the virtues of secularism (at meetings of the Organization of Islamic Countries as well as bilateral visits).

The AKP government came to adopt a balanced approach to the United States and EU. While it has striven hard to make Turkey conform to acquis communataire, it did not turn its back on the United States, with which Turkey has had a strategic alliance since it joined NATO in 1952. That alliance has had its ups and downs; however, on the whole, the two countries continued to have amicable relations. The United States' war on terror against Iraq without the backing of the United Nations Security Council and despite the strong opposition of such critical members of the EU as France and Germany turned out to be an acid test for those relations. On the eve of the war, the AKP government submitted to Parliament a resolution to allow the deployment of some American troops in southeastern Turkey along the Iraq border and the transit of other American troops through southeastern Turkey on their way to Iraq. Some influential groups in the political establishment in Turkey opposed the resolution. The president of the Republic, Ahmet Necdet Sezer, argued that Turkey could not give support to a war that did not have the blessing of the UN. The secularly oriented opposition party, the Republican People's Party (Cumhuriyet Halk Partisi, or CHP), too, did not provide support, basically for political reasons and also because the 
CHP and most of the secular intelligentsia in Turkey continued to perceive the AKP as a deadly threat to the secular Republic. The CHP and the intelligentsia have attributed to each and every AKP program and policy an ulterior motive. In their view, the party has been continuously engaged in takiyye (dissimulation), hiding its 'true intention of bringing to Turkey a state based on Islam or sharia rule.' Consequently, the CHP has resolved to undermine whatever the AKP government tried to do. A sizeable group of AKP parliamentarians, too, were against the government's resolution. Some among the latter had Kurdish backgrounds, and as such, they in all probability thought Turkey's involvement in the war would have made an independent, or at least an autonomous, Kurdish entity more difficult in the wake of the impending war. Some other AKP parliamentarians continued to have sympathies towards the Third Worldist tendencies that were entertained by the AKP's predecessors and the Felicity Party.

In the event, the resolution was defeated in a rather close vote. Soon afterwards, however, the AKP government was successful in obtaining the approval of Parliament for the transit of American planes as well as for the deployment of Turkish troops in Iraq in the post-war period to help the allied troops and administration in the latter's efforts to stabilize the country and achieve that country's transition to democracy. ${ }^{4}$ In January 2004 Erdoğan made a state visit to the United States which further mended fences between that country and Turkey. In a presentation that he made at Harvard University during his visit, Erdoğan pointed out that there are those who claim that the EU countries and the United States come from different planets, but, he stated, the planets in question were in the same solar system and therefore shared many values, which are also precious to Turkey. His perception of the United States and European Union along these lines must have been helped by the fact that during his visit to Washington, he realized that US-Turkey relations would now progress from solely strategic issues to strategiceconomical-political cooperation. That shortly after his State of the Union speech in January 2004, in which he categorically stated that the United States did not need a 'permission slip' from others to defend its homeland, the US president, George W. Bush, turned to the UN for help in the smooth transition of Iraq to democracy and that more generally the United States no longer tended to support authoritarian regimes and, instead, was striving to bring democracy, even if by force, rather than resorting to 'normative power,' should have further convinced Erdoğan that the United States and the EU share similar ideals. 
In his presentation at Harvard University, Erdoğan also argued that the EU was not a union of coal and steel, that it was not first and foremost an economic union; nor was it a Christian club. He stated that since what holds the EU together is certain values, the most important of which is democracy, it should admit Turkey into its ranks because, although 98 per cent of its population is Muslim, Turkey has always had a Western vocation.

\section{Nationalism}

Until the late nineteenth century, ethnicity was an alien concept to the Turks. In the Ottoman Empire there were only two identities - Muslim and non-Muslim. It was the Europeans who coined the terms 'Turk' and 'Turkey.' For the Ottoman Turks, the term 'Turk' meant no more than an unrefined person. When, in the nineteenth century, most nonMuslims left the empire to establish their own independent states, the Turks attempted to hold the country together by resorting first to Ottomanism (because some non-Muslims were still around) and secondly to Islamism (when virtually all non-Muslim elements had left) (Mardin 1969; Arai 1991).

It is true that from the late nineteenth century onward, the Turks began to use the term 'Turk' in its ethnic sense; however, it was used in a defensive manner. They started talking about the good qualities of the Turks, but they did not look down upon other ethnic groups. The rationale behind their acting in this manner was to regain their selfconfidence and do away with the inferiority complex that they had begun to develop as a consequence of having continually lost to their European adversaries from the late sixteenth century onwards.

During the first two decades of the twentieth century, there were two concepts of nationalism in the Ottoman Empire. One was based on shared culture. According to this version, the indigenous culture, which was sharply differentiated from civilization, constituted the basic bond that held people together and turned them into a nation. The second concept of nationalism was based on language. This version had the ultimate aim of integrating the Anatolian Turks with the Turks in Russian central Asia (Arai 1992). Having no policies of irredentism, Atatürk, the founder of the Republic, and his associates chose to adopt nationalism based on shared culture.

Atatürk argued that the peoples of Anatolia belonging to different religions and ethnic groups had lived together for several centuries 
and consequently had gone through a mutual acculturation process. Consequently, when the Republic was proclaimed, what these peoples shared in cultural terms was far greater than that on which they differed. He pointed out that when the need arose to give these peoples a common name, the term 'Turk' was chosen because at the time it was the most familiar one (Göçgün, 1992; Sarınay 1990). It follows that the founders of the Republic subscribed to cultural rather than ethnic nationalism. They took 'Turk' as a nominal term, that is, as a means of reference rather than definition. They perceived the Turkish nation as a mosaic. In their view, the Turks, Kurds, Bosnians, Lazes, and other ethnic groups together made up the Turkish nation. At the time, Atatürk, who was later criticized by his detractors for the 'exclusiveness of Atatürkism regarding the "other,"' even talked of 'the peoples of Turkey' rather than the 'Turkish people.' Along the same lines, at the Lausanne Peace Conference, which was convened following the Turkish War of Independence (1919-22), the Turkish delegation, led by İsmet Inönü, readily agreed to granting to the different elements of the nation such cultural rights as expressing oneself in one's own language and celebrating on special days.

In turn, the Constitution of 1924 introduced civic nationalism. It stipulated that those who professed loyalty to the Republic were Turks. Consequently, legally speaking, the nationalism enunciated by the Constitution took the non-Muslims living in Turkey into the fold of Turkish nationalism. The qualification 'legally speaking' is needed because, despite the clear-cut provision in the Constitution, in practice, Turkish nationalism continued to display unmistakable signs of cultural nationalism. In the 1940s and 1950s one came across strong antinon-Muslim sentiment in Turkey. One such instance was the 1942-4 capital levy, which was enacted to tax unearned wealth that, it was thought, had accrued to some people through black-market transactions. Those were the years when quite a number of goods were in great shortage in Turkey because of the Second World War. In the event, only non-Muslims were taxed, and many to gills (Ökte 1987). Another example was the 1957 anti-Greek demonstrations in Istanbul in the heat of the escalating conflict between Greece and Turkey over Cyprus. It was reported that the demonstrations had been planned by the government but had gotten out of control and ended up with the deliberate destruction of numerous shops in downtown Istanbul, many of which were owned by non-Muslim citizens (Ahmad 1975, 545). In recent decades, there has been no such anti-Muslim sentiment in 
Turkey, even when several Turkish diplomats were killed by the Armenian organization ASALA. On the eve of Christmas Day 2003, Erdoğan congratulated the Christian citizens of Turkey on this sacred day by declaring, 'I share with great happiness the feelings of love, solidarity, and tolerance which are always felt intensely on the anniversary of the birth of Jesus Christ, and view them as the common values of humanity. I pray to God that this anniversary of the birth of Jesus Christ will be an occasion for glad tidings for everybody. ${ }^{5}$

It should be noted that in the late 1930s and 1940s, some Turkish intellectuals referred to Kurds in Turkey as 'mountain Turks' (because for a long time the Kurds had lived in the high fastnesses of southeastern Turkey), and some Turkish statesmen talked of 'blood' and 'descent' as the constitutive elements of the Turkish nation. These developments led some students of Turkey to argue that the Republic's nationalism was neither civic nor even cultural, but that it was ethnic nationalism. What this view neglected to take into account was that the intellectuals who referred to the Kurds as 'mountain Turks' did not belong to the public decision-making circles in Ankara. In any case, the target group of these intellectuals was the communists and not nonTurkish ethnic groups. Still, after a while, the intellectuals in question were tried in the courts for being champions of ethnic nationalism and thus ethnic separatism. The discourse of some Turkish statesmen at the time, which also smacked of ethnic nationalism, was an outcome of the policy of appeasement that the Turkish government was then pursuing against the German government's efforts to persuade Turkey to try to liberate the Turkic groups under Soviet rule and thus oblige the Soviets to engage some of their troops on the Asian front. As soon as it became apparent that the Germans were losing the war, that discourse was discontinued (Erdoğan 1990, 98-117).

Such isolated and/or short-lived diversions toward ethnic nationalism in Turkey came only in the wake of a number of intermittent Kurdish uprisings in the years 1925-38. From the early 1940s to the present and even in the post-1984 period, when until recently there were armed clashes between the separatist PKK (Kurdish Workers' Party) and government forces, the Turks have not on the whole entertained ethnic nationalism. They developed an unmistakable hostility to the PKK but, apart from some exceptions, not to the Turkish citizens of Kurdish origin as a whole.

From the late 1960s to the present, the Nationalist Action Party (Milliyetçi Hareket Partisi, or MHP) has carried the nationalist flag in Tur- 
key. ${ }^{6}$ Most of the intelligentsia in Turkey has always viewed this party as an extreme right organization. It is true that in his youth in the 1940s, its leader, Alparslan Türkeş, toyed with the idea of ethnic nationalism (Landau 1982; Arlkan 1998). At the time, he pointed out that those who spoke Turkish with a different accent could not be considered proper Turks (Türkeş 1968, 13). Later, however, Türkeş abandoned such ethnic nationalist discourse and adopted cultural nationalism. He came to the conclusion that only those people who have similar feelings and aspirations make up a nation; in the mature Türkeş's opinion, the Turks and the Kurds had a common culture, and thus they together constituted a homogeneous nation (Türkeş 1966, 72). During the 1970s, the MHP took upon itself the mission of defending the country against communism. In Türkeş's view, Turkey was going through a spiritual crisis. In order to overcome that crisis, it was necessary to revive the Turks' authentic communitarian values. As well, Türkeş was preoccupied with the goal of modernizing the country. In order to accomplish that goal in the shortest possible time, he was not averse to resorting to authoritarianism. He also kept his distance from the outside world.

At the same time, the party had no problems with the Kurds. Even during the post-1984 period, when Kurdish separatism reached its nadir in Turkey, Türkeş did not have harsh words concerning the Kurds. On the contrary, he made important contributions to the prevention of a rise in anti-Kurdish sentiment in the country. In the post1980 period, Türkeş shed his earlier authoritarianism; he became a seasoned and respected politician who sought harmony and consensus in politics (Heper 2001, 7-8).

Türkeş died in 1997. Since then, Devlet Bahçeli has been the leader of the MHP. The party was a member of a coalition government with the centre-left Democratic Left Party (Demokrat Sol Parti, or DSP) and the centre-right Motherland Party (Anavatan Partisi, or ANAP) from 1999 to 2002. Bahçeli acted as deputy prime minister in that government. According to him, the markers of nationalism are neither race nor ethnicity nor imperialism. Bahçeli has a civic notion of nationalism. His is based on measured patriotism. Bahçeli once said, 'It is not important which particular identity the [Kurdish] people in the southeast think they have. What is important is that they should be of the opinion that Turkey is indispensable for them' (Nihat and Cemiloğlu 1995, 12). On another occasion, he declared, 'It would not bother us if a Kurd is called "Kurd" as long as that statement is not made with the ultimate aim of disrupting national unity in this country and putting an end to the unitary structure of the Turkish republic' (Heper and Ince, forth- 
coming). Along the same lines, Bahçeli thinks, 'Nobody should take advantage of "being a Turk" and so discriminate against other ethnic groups. The word "Turk" needs to be used in a nominal sense: we call everybody "Turk" since we have to call everybody who lives in this country by a common name' (ibid.). In Bahçeli's opinion, a political party should not represent only one ethnic group. Not unlike Türkeş, he is also interested in elevating Turkey to the level of contemporary civilization. However, unlike the young and semi-mature Türkeş, Bahçeli has no problem with democracy. In his view, 'democracy would foster respect for different views and ideas and thus make a significant contribution to social peace and harmony' (Bahçeli 2002a, 7).

Bahçeli's nationalism is also open to the outside world. As he once put it, 'If there is a national state, there would be a national identity; if there is a national identity, there would be nationalism. However, this would not mean that the nationalism in question would be an inwardlooking one' (Nihat and Cemiloğlu 1995, 12). Bahçeli thinks that the Turkish economy should be fully integrated with the world economy. He views globalization as a fact of life, and unlike Türkeş, he believes that the Turks should adopt universal values.

In Bahçeli's opinion, Turkey's relations with the outside world should not have major adverse effects on that country. He thinks that people everywhere would live in peace and harmony if their relations are based on global justice. In Bahçeli's estimation, Turkey should not terminate its relations with the EU. However, he believes that some Europeans are trying to promote Kurdish nationalism in Turkey. He argues that such efforts may lead to the emergence of a new cultural cleavage in Turkey, which would be difficult to resolve by democratic means. He contends that the EU should not display a double standard concerning terrorism, adding that in all international legal charters, terrorism is considered an act against humanity. Bahçeli thinks the EU should make a clear distinction between terror and human rights, and he calls upon the EU to refrain from engaging in unjust behaviour against the Turks (Bahçeli 2002a, 7). Despite his reservations about the EU, Bahçeli is not against Turkey's becoming a full member of the Union. In the 1999-2002 period, he supported the government's efforts to move Turkey in that general direction.

\section{The Military}

The Ottoman Empire was founded by a warrior class. Consequently, the military occupied a prominent place in the governance of the new 
state. The military also played an important role in Turkey from the end of the nineteenth century to the founding of the Republic in 1923. It became first the object and then the subject of modernization. The graduates of the modern military schools opened in the last decades of the nineteenth century played a prominent role in the removal of Sultan Abdülhamid II (who reigned from 1876 until 1909) from the throne and the reinstatement of the constitutional monarchy in 1909. In the 1912-18 period, when the Committee of Union and Progress, made up of intellectuals, civil servants, and officers, controlled politics from behind the scenes, officers were involved in the day-to-day politics (Turfan 2000). This did not augur well for professionalism in the military. The military learned its lesson; the idea that ultimate authority should belong to civilian governments and that therefore the military should stay out of politics to the extent it could help, became a maxim to which the military faithfully subscribes to this day (Hale 1994).

Being for long the subject of modernization, the military believed in rational democracy; in its view, politics consists of intelligent debate among well-intentioned and knowledgeable persons in order to find out what is best for the country (Heper 1985, chap. 3). This led it to take power into its own hands in 1960-1, 1971-3, and 1980-3. Some students of Turkish politics have attributed the active role the military played in that country to the 'military's being power hungry' and/or to 'its organic relations with the propertied classes.' These arguments are less than satisfactory. In 1960 the military was concerned with growing threats to secularism, as well as the beginning of fratricide between members of the political party in power, the Democratic Party (Demokrat Parti, or DP), and the opposition party (CHP). In 1971, pitched battles in the streets between left- and right-wing militants prompted the military into action. Its reason for the 1980 intervention was 'the threat of political Islam' as well as hints of ethnic terrorism. In each case, the military came to the conclusion that the politicians in power were not competent enough to deal with the critical problems the country faced (Karpat 1988; Tachau and Heper 1983).

Since they believed that the ultimate authority belonged to civilian governments, each time they took power into their own hands, officers felt an obligation to justify their actions. In 1960 they found solace in a report prepared by the then most prominent professors of law, which the military had recruited. The professors argued that by resorting to anti-constitutional acts, the DP had lost its political legitimacy. In the subsequent interventions, the military referred to the 1961 Constitution 
and the Internal Service Act of the Turkish Armed Forces, both of which made the military responsible for averting threats to the internal as well as the external security of the country and authorized it to use force if absolutely necessary. In the event, the military in Turkey has not considered its interventions in politics an exploitation of its power but a legal responsibility it could not shirk (Heper and Güney 2000; Sakallığlu 2002).

As in the last decades of the nineteenth century, so too in the twentieth century, the military continued to be the object of modernization. Particularly following Turkey's joining NATO in 1952, the military became a modern and professional institution. Therefore the colonels' coup of 1960 , when several young officers became members of the Junta, was in later years not looked upon with favour. This was because such coups could easily politicize the military, which in turn would have had adverse effects upon its professionalism. Consequently, the 1971 and 1980 interventions turned out to be generals' coups. Also from 1961 to 1980 , the scope of what the interveners should concern themselves with was consistently reduced.

A further step that the military took in order to distance itself from active politics to the greatest extent possible was putting an end to its practice of taking power directly into its own hands. Thus when, in 1997, it came to the conclusion that the coalition government of the religiously oriented Welfare Party and the secularly oriented True Path Party (Doğru Yol Partisi) were rather lax towards what it considered to be a serious threat arising out of political Islam, it harshly criticized the government in the National Security Council (MGK), ${ }^{7}$ gave briefings to members of the higher judicial tribunals, university administrators, and the media, and encouraged the people to turn the lights off and on as part of a general protest towards the government. Under such pressure, the government had no option but to resign. On that occasion, then president Süleyman Demirel, who had successfully tried to de-escalate the political crisis in question, argued that the commanders serving in the MGK had been not acting as representatives of the military but as top experts on security matters. The military readily agreed with this particular interpretation (Heper 2002).

In recent decades, the military has considered political Islam and ethnic nationalism as the two most critical threats for the internal as well as the external security of Turkey. It has consistently sent unmistakable messages concerning those two issues that it could not remain inactive if appropriate measures were not taken. On one such occasion, 
then chief of the general staff General Hüseyin Kivrıkoğlu pointed out that 'if necessary, the 1997 spirit would continue for thousand years. ${ }^{8}$ On the other hand, the military has wished to see not only the consolidation of democracy in Turkey but also its deepening. Thus it has supported Turkey's becoming a full member of the EU. This is what then deputy chief of the general staff General Yaşar Büyükanıt once said: 'Turkey's membership in the European Union is a must for the fulfilment of Atatürk's grand design of modernization. In any case, Turkey's European Union project overlaps with its social, political, and economic projects. ${ }^{\prime 9}$ The present chief of the general staff, General Hilmi Özkök, too declared that 'the Turkish Armed Forces had always acted as the pioneer of modernization in Turkey. Turkey's accession to the European Union will finally help realize that goal. ${ }^{10}$

Because the military thinks that Turkey should belong to the EU, it did not object to having more civilians in the MGK. It also gave its consent to the constitutional amendment that the MGK should no longer 'notify the government of its recommendations,' but that it should 'make suggestions to the government as a consultative organ' and do so when required, not itself taking the initiative. Furthermore, the military had no qualms about a constitutional amendment that would have made it possible to challenge the constitutionality of the legislation enacted during the 1980-3 military intervention, the removal of the military judge from the State Security Courts, and the secretarygeneral of the MGK being a civilian.

In fact, the military urged the government to complete Turkey's work of adapting the Turkish legal system to the Maastricht and Copenhagen criteria as soon as possible. Critical here was the clash of opinion within the 1999-2002 coalition government about abrogation of capital punishment and about broadcasting and education in Kurdish. While the other members of the coalition government looked at these changes with favour, the Nationalist Action Party of Devlet Bahçeli was for a while not enthusiastic about them. The party was of the opinion that abrogation of the death sentence, and therefore not carrying out the sentence given by the court to Abdullah Öcalan, the former leader of the separatist PKK, who was held responsible for the death of close to 35,000 people from 1984 to 1999, would severely offend the relatives of those who perished. Furthermore, according to that party, broadcasting and education in Kurdish would have led to the partition of Turkey.

In the past, the military too had thoughts along the same lines. Recently, however, it has softened its position. It suggested that capital 
punishment be abolished, but along with it, another amendment should be made so that those sentenced to life imprisonment should never benefit from an amnesty. In the past, the military was against broadcasting in Kurdish too. It now thinks that news in Kurdish can be broadcast with the proviso that it be broadcast on only one of the state television channels and at designated hours. According to the military, education in Kurdish is unacceptable, because Turkish is the official language of Turkey, which is a unitary state. However, for the teaching of different mother tongues that exist in Turkey, including Kurdish, special courses can be offered to fourth- and fifth-year students of grade schools following regular class hours. Thus when, in the summer of 2003, such liberal provisions were enacted into law by Parliament, the military accepted them in good faith.

It is clear that, like Turks in general, officers have a European outlook. However, not unlike the MHP, the military too thinks that Europe should be cognizant of the threats Turkey faces to its internal and external security and therefore should not impose on the country measures that would imperil its vital security interests. The generals argue that none of the European countries are under the threats that Turkey has faced for a long time and continues to face. They point out that no European country would have supported terrorist organizations if these had as their goal the partition of a neighbouring country, had made the exporting of its regime to one of their neighbouring countries a state policy, and had shown on its official maps part of the territory of a neighbouring country within its own borders. They argue that in no democratic country such as Germany, France, and United States could democracy and freedom of speech be exploited for separatist aims. The generals make it clear that if some international organizations and European countries force Turkey to make a choice between full membership in the EU and the country's national and territorial integrity, the military's choice would be the latter. The military complains that in no international platform has Europe granted Turkey its rights. It states that Europe did not support Turkey's Cyprus policy, and that it backed Armenia on the Nagorno-Karabakh conflict and frequently placed the genocide issue, which Turkey rejects, on the agendas of its parliaments. Still, the military emphatically points out that whether or not Europe considers Turkey a country belonging to Europe, Turkey is of Europe. It is so because the civilizational roots of the Republic are mostly in Europe. ${ }^{11}$

It should be noted that the military's perception that Europe does not 
want Turkey to be in its fold sometimes prompts certain top generals to toy with the idea of Turkey further promoting its relations with some other countries. On one occasion, then secretary-general of the National Security Council, General Tuncer Kılınç, argued that since the EU had an unfavourable attitude towards Turkey, that country should seek ways and means of further developing relations with Iran and the Russian Federation. This comment started a heated debate in Turkey. Chief of the general staff General Kıvrıkoğlu, however, clarified the military's approach to the issue in question. He argued that one should scrutinize General Kılınç's comments carefully and not jump to hasty conclusions. He pointed out that Turkey would, of course, develop relations with such countries as Iran, but it cannot have cordial relations with such countries. In Kıvrıkoğlu's opinion, no officer in Turkey could think of setting aside Turkey's civilizational mission, which is Western-oriented. By taking this particular position, Kıvrıkoğlu once more implied Turkey's first preference - that of becoming a member of the EU because Turkey perceives itself as belonging to the same civilization as EU countries. In early August 2003 a similar exchange took place between General Kılınç and the present chief of the general staff, General Hilmi Özkök. At the end of August of the same year, General Kılınç and a few other generals who thought along the same lines were retired. Since then, similar isolated statements continued to be made by some generals, though less frequently. However, the chief of the general staff no longer states the position of the military in general on this matter, because on such occasions several leading members of the media have protested such statements, pointing out that individual generals cannot speak on behalf of the military and that taking a negative stance towards the EU is not in the best interests of the country. Faced with such determined opposition, the individual generals who have expressed their opinions have taken back their statements. To use the terminology of the editors of this volume, in recent years Turkey has made considerable progress towards substituting 'civilian power' for 'military power,' which in any case was not continuous or extensive.

\section{The Turkish Experience and a Security Community in the Mediterranean Region}

The Turkish experiment in nation-building and democracy may be a model for the countries around the Mediterranean. It could show that what was once a traditional Muslim country can become a relatively 
respectable member of the international community while retaining some its indigenous characteristics. It was of course Japan, not Turkey, that first achieved that feat. However, the fact that Turkey brought about the gigantic transformation in question has a special significance because it has taken place in a particular civilizational framework that of Islam - which according to Orientalist thought could not be capable of realizing even much less spectacular reforms.

On the whole, the editors of this volume, too, seem to be rather pessimistic about this issue. They view 'engaging Muslim states in a "dialogue of civilization"' as an almost insurmountable task, and consequently, they 'do not believe that a Mediterranean pluralistic security community will happen in our lifetimes.' Admittedly, there are major obstacles for an intellectual and political shift on the part of many Middle Easterners towards a sympathetic attitude concerning the project that this volume addresses. ${ }^{12}$ There are also reasons to be optimistic, however. The unexpected does happen. Who would have thought that the Soviet Union could have collapsed so suddenly? Who would have thought $\mathrm{Mu}^{\prime}$ ammar Gaddafi would have begun to act in a more accommodating manner in his relations with the West?

If we turn to the Mediterranean south and east as a whole, it is possible to point to some recent developments that may be the harbinger of more substantial transformations in the foreseeable future. In the wake of two serious earthquakes during which Greeks and Turks rushed to the help of one another, there has been a considerable amelioration in the conflict between the two countries. Consequently, they have come quite close to solve their half-century-old conflict over Cyprus. One comes across a similar weariness concerning big questions and a turn to a new, more pragmatic, less-ideological politics in the Arab Middle East too (Makiya 1995). As compared to the Nasser and Sadat periods, under Hosni Mubarak, Egypt has adopted a middle-of-the-road policy in the conflict between fundamentalist Islam and secularism. In recent years, Iran has made limited progress towards a non-Ayatollah regime much faster than could be predicted in the wake of the 1979 revolution. Although in many countries, authoritarian regimes remain intact, there is a growing desire for change. In the process, such issues as violations of human and civil rights, the demands of minorities, and projects of reform have become part of the public debate and discourse. More generally, the fiscal crises that the Arab regimes have faced during recent years has led some of them, though cautiously, to 'bring society back in.' They have begun to privatize their economies, political par- 
ties have been formed, relatively honest elections have been held, and voluntary associations have started to spring up (Sivan 1997; Eddin 1998). Such countries as Jordan, Lebanon, Morocco, and Kuwait have made considerable progress towards democracy.

A more substantial political opening may be on the cards now that Israel's Ariel Sharon has begun to talk of withdrawing Israeli settlements from certain areas and rerouting the fence between its country and a potential Palestine state; a solution to the Israeli-Palestine conflict, which also, of course, needs the Palestinians to reciprocate in comparable terms, may facilitate the solution of the Arab-Israeli conflict and decrease the general tension in the area. That the United States began striving to bring democracy to the region rather than supporting authoritarian regimes there may erase from the minds of people in the region the image of the United States as the 'Great Satan,' provided, of course, that the democracy in question does not allow sectarian and ethnic conflict to flourish and instead introduces accountability in government and raises the socio-economic standards of life in the region.

Is it not possible within the framework of the present project to accelerate change in the region, glimmers of which we have recently begun to witness? Earlier, some of the causes behind the Turks' partial borrowing from an 'alien civilization' during the Ottoman period were discussed. One factor which has not so far been mentioned and which, in fact, enabled the Turks in the republican period not to borrow partially from another civilization but instead to take the bold step of crossing the civilizational border altogether was the reinterpretation of that other civilization by the founder of Turkey, Atatürk. He made the argument that what passed as Western civilization was, in fact, the property of all nations because they all contributed to it at some point or another. Atatürk stated that the civilization that the Turks were going to join was 'contemporary civilization,' not 'Western civilization.' With this reasoning, it was easy for the founder of the Republic to make the argument that the Turks were not going to make a transition to an 'alien civilization.'

The editors of this volume argue that the Barcelona process has to confront the notion that region-building in the Mediterranean means engaging the Muslim world, that a large majority of Muslim people are bitter and resentful, and that they do not want to "converge," if by convergence we mean the adoption of liberal ways.' They then suggest that, among other things, 'the development of shared narratives and myths' would help to engage Islam in the Barcelona process. The Turk- 
ish transformation suggests that it would help greatly if what are emphasized are those particular myths and narratives about certain past and present components of the Western and Eastern civilizations that have close affinity to each other. This 'cross-cultural,' rather the 'universalistic,' strategy would enable members of different civilizations not only to tolerate but also to respect each other's civilizations. ${ }^{13}$ Once this happens, what previously seemed alien may begin to become first palatable and then even desirable.

If this argument does not miss the mark, the Barcelona project should help people around the Mediterranean to substitute 'contemporary civilization' for 'Western civilization' and to openly acknowledge the contributions the countries around that sea also made to that common contemporary civilization. This process may lead the peoples of the region to have a fresh look at the project of developing a pluralistic and loosely coupled security environment in their region.

Did the Mediterranean south and east actually make contributions to the contemporary civilization, and are there indeed similarities between the civilizations of the people around the Mediterranean? One should keep in mind that all three monotheistic religions - Judaism, Christianity, and Islam - have drawn from the ancient Middle East, from Greco-Roman antiquity, and from Jewish revelation and prophecy (Lewis 1993b, 177). It is not, therefore, surprising that their tenets concerning morality, for instance, are similar. These tenets may be viewed as ethical values common to the three monotheistic religions. Also, it was the people who once lived in the Mediterranean east that acted as a conveyor belt between ancient Greek and Chinese civilizations, on the one hand, and present-day European civilization, on the other.

With regard to Islam itself, in contrast to Islamic history in general, the classical Islamic thought carried with it ideas that were not alien to democracy; in fact, with some reservations, it may be suggested that the opposite was true. The classic Islamic idea of sovereignty drew upon the notions of election, contract, consensus, and accountability. It is true that the electorate was never carefully designated, nor was any procedure of election ever formulated, but the elective principle remained central at least to Sunni jurisprudence. That jurisprudence also stipulated that if the caliph (earlier the Prophet's successor, later a Muslim ruler in general) failed in his duties, he could be removed from office. Consequently, in theory at least, the Muslim ruler was not above the law. Sunni jurisprudence also contained the idea of consultation; it 
was stipulated that ruler should consult with suitably qualified advisers. It is true that the consultation in question had no relation to the representative principle, for the ruler was to consult in order to make sure that he correctly interpreted the God-given law; but the consultative principle of the classic Islam at least took a stance against one-man rule (Lewis 1993a). Islam has not looked upon Judaism and Christianity as false, and Muslims philosophers referred to Aristotle as the First Master (Tibi 1997, 25).

It is well known that feelings of shame and guilt are quite pervasive in some countries around the Mediterranean. The proposed shifting of gears may help to convince people in the south and east of that region that such an institution as democracy, considered by most people there as Western (i.e., the handiwork of, among others, the 'Great Satan') is not an altogether Western institution. Consequently, the feelings of shame and guilt and the resulting bitterness may be replaced by feelings of honour and satisfaction and therefore by an accommodating attitude. People in the Mediterranean south and east, as well as people in the Mediterranean north, would no longer think of $9 / 11$ as the result of a clash of civilizations, but as a consequence of terrorism deriving from a particular history that they no longer consider their own or the consequence of a legacy perpetuated by some Muslims who are unaware of the fact that none of the monotheistic religions condones violence which targets innocent people. In the process, countries around the Mediterranean would view one another with less prejudice and more openmindedness. This new perception on their part would increase their willingness to cooperate. They would think that they have similar legacies with people whom until now they have thought of as 'the other.' It would start an endogenous change based on a crucial learning process that has been the trademark of the Turkish experience - a transformation to which the editors of this volume, as well as Etel Solingen's chapter, too attribute great significance.

\section{NOTES}

1 See below for an elaboration.

2 On religiously oriented political parties in Turkey, see, inter alia, Heper 1981; Alkan 1984; Toprak 1984; Özbudun 1987; Gülalp 1996; Ayata 1996; White 1997; Kasaba 1998.

3 The following account of Recep Tayyip Erdoğan and his Justice and 
Development Party primarily draws upon Heper 2003a, 2003b, and forthcoming.

4 Nevertheless, as a result of Iraqi opposition and a decision by the American administration, Turkish troops were not deployed in Iraq.

5 Sabah (Istanbul daily), 24 December 2003.

6 On this party, see Çalık 1995 and Tepe 2000.

8 Hürriyet, 4 September 1999.

9 Hürriyet, 30 May 2033.

10 Hürriyet, 29 May 2003.

11 Interview with retired general Kenan Evren, who as chief of staff, had led the 1980 military intervention (13 August 2003, Marmaris, Turkey). On this issue, also see Heper, Öncü, and Kramer 1993.

12 See, inter alia, Talbi 2000 and Sarılghalam 1997.

13 For a view along the same lines, see Tibi 1997.

\section{REFERENCES}

Ahmad, Feroz. 1975. The Turkish Experiment in Democracy, 1950-1975. London:

C. Hurst.

Alkan, Türker. 1984. 'The National Salvation Party in Turkey.' In Metin Heper and Raphael Israeli, eds., Islam and Politics in the Modern Middle East. London: Croom Helm.

Arai, Masami. 1991. 'An Imagined Nation: The Idea of the Ottoman Nation as a Key to Modern Ottoman History.' Orient 29: 1-20.

- 1992. Turkish Nationalism in the Young Turk Era. Leiden: E.J. Brill.

Arikan, E. Burak. 1998. 'The Programme of the Nationalist Action Party: An Iron Hand in a Velvet Glove.' Middle Eastern Studies 34: 120-34.

Ayata, Sencer. 1996. 'Patronage, Party, and State: Politicization of Islam in Turkey.' Middle East Journal 50.1: 109-14.

Bahçeli, Devlet. 2002a. 'Türkiye-AB İlişkilerinde Kırılma Noktaları' (Fault Lines in the Turkey-EU Relations). Türkiye ve Siyaset 7: 7.

- 2002b. Yeni Çă̆a Bakiş: Eleştiriler, Tespitler, Öneriler (Glancing at the New Era: Criticisms, Views, Proposals). Opening and closing speeches made at the Sixth MHP Congress. Ankara: MHP.

Braude, Benjamin, and Bernard Lewis. 1982. Christians and Jews in the Ottoman Empire. Vol. 1. Central Lands. New York: Holmes and Meirs.

Çalık, Mustafa. 1995. Siyasi Kültür ve Sosyolojinin Bazi Kavramlari Açisindan MHP Hareketi: Kaynaklari ve Gelişimi, 1965-1980 (The Nationalist Action Party Movement from the Perspective of Political Culture and Some Socio- 
logical Concepts: Its Background and Development, 1965-1980). Ankara: Cedit Neşriyat.

Çarkoğlu, Ali. 2004. 'Religiosity, Support for Şeriat, and Evaluations of Secularist Politics in Turkey.' Middle Eastern Studies 40.2: 111-36.

Çarkoğlu, Ali, and Binnaz Toprak. 1999. Türkiye'de Din, Toplum ve Siyaset (Religion, Society, and Politics in Turkey). Istanbul: TESEV.

Dumont, Paul. 1987. 'Islam as a Factor of Change and Revival in Modern Turkey.' In Sabri Akural, ed., Turkic Culture: Continuity and Change. Turkish Studies Series no. 6. Bloomington: Indiana University Press.

Eddin, Ibrahim Saad. 1998. 'The Troubled Triangle: Populism, Islam and Civil Society in the Arab World.' International Political Science Review 19.4: 37385.

Erdoğan, Günay Göksu. 1990. 'The Case of Racism-Turanism: Turkism during the Single-Party Period, 1931-1944.' PhD dissertation, Boğaziçi University, Istanbul.

Göçgün, Önder. 1992. 'Atatürk'e Göre “Millet” Kavramı' (The Concept of 'Nation' according to Atatürk). Türk Kültürü 30.355: 641-64.

Gülalp, Haldun. 1996. 'Political Islam in Turkey: The Rise and Fall of the Refah [Welfare] Party.' Muslim World 89.1: 22-41.

Hale, William. 1994. Turkish Politics and the Military. London: Routledge.

Heper, Metin. 1981. 'Islam, Polity, and Society in Turkey: A Middle Eastern Perspective.' Middle East Journal 35: 345-63.

- 1985. The State Tradition in Turkey. Walkington, UK: Eothen Press.

- 1997. 'Islam and Democracy in Turkey: Toward Reconciliation?' Middle East Journal 51: 32-45.

- 2001. 'Turkey: Yesterday, Today, and Tomorrow.' Journal of South European and Black Sea Studies 1.3: 1-19.

- 2002. 'The Military-Civilian Relations in Post-1997 Turkey.' In George Cristian Maior and Larry Watts, eds., Globalization of Civil-Military Relations: Democratization, Reform, and Security. Bucharest: Enciclopedica Publishing House.

- 2003a. 'Islam, Modernity, and Democracy in Contemporary Turkey.' Muslim World 93.2: 157-83

- 2003b. 'The Victory of the Justice and Development Party in Turkey.' Mediterranean Politics 8.1: 127-34.

- Forthcoming. 'Conservative-Democratic Government by Devout People: The Justice and Development Party in Turkey.' In Ibrahim Abu-Rabi, ed., Blackwell Companion to Contemporary Islamic Thought. New York: Blackwell. Heper, Metin, and Aylin Güney. 2000. 'Military and the Consolidation of Democracy: The Turkish Case.' Armed Forces and Society 26: 625-47. 
Heper, Metin, and Başak İnce. Forthcoming. 'Devlet Bahçeli and "Far-Right" Politics in Turkey, 1999-2002.' Middle Eastern Studies.

Heper, Metin, Ayşe Öncü, and Heinz Kramer, eds. 1993. Turkey and the West: Changing Political and Cultural Identities. London: I.B. Tauris.

Heper, Metin, and Sabri Sayarı, eds. 2002. Political Leaders and Democracy in Turkey. Lanham, MD: Lexington Books.

İnalcık, Halil. 1968-70. 'Islam in the Ottoman Empire.' Cultura Turcica 57: 19-29. Karpat, Kemal H. 1959. Turkey's Politics: The Transition to a Multi-Party Politics. Princeton: Princeton University Press.

- 1988. 'Military Interventions: Army-Civilian Relations in Turkey before and after 1980.' In Metin Heper and Ahmet Evin, eds., State, Democracy and the Military: Turkey in the 1980s, 137-50. New York: Walter de Gruyter.

Kasaba, Reşat. 1998. 'Co-Habitation? Islamist and Secular Groups in Modern Turkey.' In R. Hefner, ed., The History and Cross-Cultural Possibility of a Modern Ideal. New Brunswick, NJ: Transaction Publishers.

Landau, Jacob M. 1982. 'The Nationalist Action Party in Turkey.' Journal of Contemporary History 17: 587-606.

Lewis, Bernard. 1961. The Emergence of Modern Turkey. London: Oxford University Press.

- 1993a. 'Islam and Liberal Democracy.' Atlantic Monthly 271.2: 89-94.

- 1993b. Islam and the West. New York: Oxford University Press.

Makiya, Kanan. 1995. 'Toleration and the New Arab Politics.' Journal of Democracy 6.1: 90-103.

Makofsky, Alan, and Sabri Sayarı, eds. 2000. Turkey's New World: Changing Dynamics in Turkish Foreign Policy. Washington, DC: Washington Institute for Near East Policy.

Mardin, Şerif. 1969. 'Power, Civil Society, and Culture in the Ottoman Empire.' Comparative Studies in Society and History 11: 258-81.

- 1971. 'Ideology and Religion in the Turkish Revolution.' International Journal of Middle East Studies 2: 197-211.

Müftüler-Baç, Meltem. 1997. Turkey's Relations with a Changing Europe. Manchester: Manchester University Press.

Nihat, Mehmet, and Emre Cemiloğlu 1995. Türk Siyasi Hayatinda Milliyetçi Hareket: Tarihi, Gelişimi, Partileşmesi ve İdeolojisi (The Nationalist Action in Turkish Political Life: Its History, Development, and Transformation into a Political Party and Ideology). Ankara: Turkuaz Ajans.

Ökte, Faik. 1987. The Tragedy of the Turkish Capital Tax. Trans. from Turkish by Geoffrey Cox. London: Croom Helm.

Öniş, Ziya. 1998. State and Market: The Political Economy of Turkey in Comparative Perspective. Istanbul: Boğaziçi University Press. 
Özbudun, Ergun. 1987. 'Islam and Politics in Modern Turkey.' In Barbara Freyer Stowasser, ed., The Islamic Impulse. London: Croom Helm.

- 2000. Contemporary Turkish Politics: Challenges to Democratic Consolidation. Boulder, CO: Lynne Riener.

Rubin, Barry, and Metin Heper, eds. 2002. Political Parties in Turkey. London: Frank Cass.

Rustow, Dankwart A. 1987. Turkey: America's Forgotten Ally. New York: Council for Foreign Relations.

Sakallığlu, Ümit Cizre. 2002. 'The Military and Politics: A Turkish Dilemma.' In Barry Rubin and Thomas A. Keaney, eds., Armed Forces in the Middle East: Politics and Strategy. London: Frank Cass.

Sarınay, Yusuf. 1990. Atatürk'ün Millet ve Milliyetçilik Anlayişi (Atatürk's Conception of Nation and Nationalism). Ankara: Türk Kültürünü Araştırma Enstitüsü.

Sarılghalam, Mahmood. 1997. 'Prospects for Civil Society in the Middle East: Cultural Impediments.' In Elisabeth Özdalga and Sune Perrson, eds., Civil Society and Democracy in the Muslim World. Istanbul: Swedish Research Institute in Turkey.

Sivan, Emmanuel. 1997. 'Constraints and Opportunities in the Arab World.' Journal of Democracy 8.2: 103-13.

Tachau, Frank, and Metin Heper. 1983. 'The State, Politics, and the Military in Turkey.' Comparative Politics 16.1: 17-33.

Talbi, Mohamed. 2000. 'Arabs and Democracy: A Record of Failure.' Journal of Democracy 11: 58-68.

Tepe, Sultan. 2000. 'Kemalism, Islamism, and the Nationalist Action Party in Turkey.' Turkish Studies 1.2: 59-71.

Tibi, Bassam. 1997. 'The Cultural Underpinnings of Civil Society in the Middle East: Islam and Democracy - Bridges between Civilizations.' In Elisabeth Özdalga and Sune Perrson, eds., Civil Society and Democracy in the Muslim World. Istanbul: Swedish Research Institute in Turkey.

Togan, Sübidey, and V.N. Balaubramanyam. 1996. The Economy of Turkey since Liberalisation. London: Macmillan.

Toprak, Binnaz. 1984. 'Politicization of Islam in a Secular Turkey: The National Salvation Party in Turkey.' In Said Amir Arjomand, ed., From Nationalism to Revolutionary Islam. London: Macmillan.

Turfan, M. Naim. 2000. Rise of the Young Turks: Politics, the Military, and Ottoman Collapse. London: Tauris.

Türkeş, Alparslan. 1966. Milliyetçilik. Istanbul: Hamle.

- 1968. 1944 Milliyetçilik Olayi (The 1944 Incident of Nationalism). Istanbul: Hamle. 
White, Jenny. 1997. 'Pragmatists or Ideologists: Turkey's Welfare Party in Power.' Current History 96.606: 25-30.

Yalman, Nur. 1969. 'Islamic Reform and Mystic Tradition in Eastern Turkey,' Archives européennes de sociologie 10: 41-2. 